\title{
Late Noninfectious Pulmonary \\ Complications in Hematopoietic Stem Cell Transplantation
}

Kevin Dsouza, Cameron Pywell, and Victor J. Thannickal

\section{Contents}

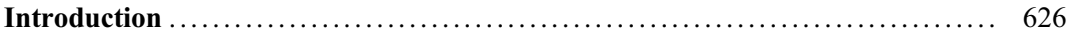

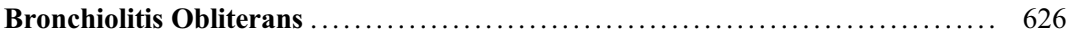

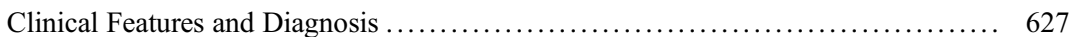

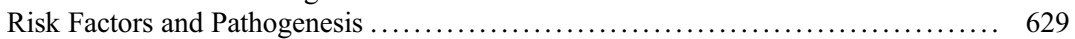

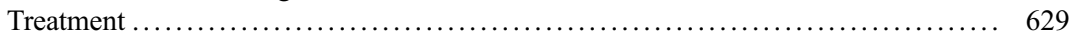

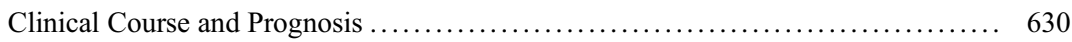

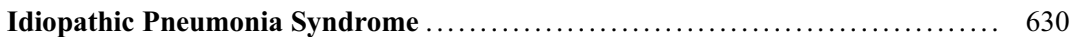

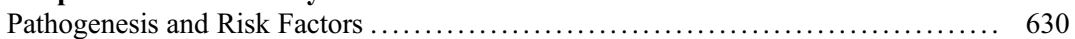

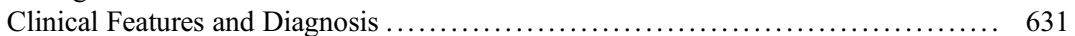

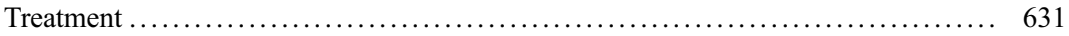

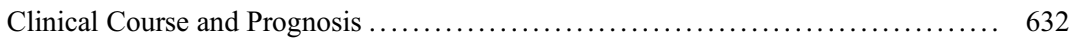

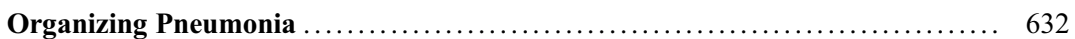

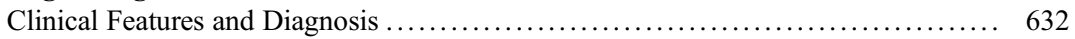

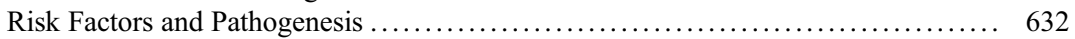

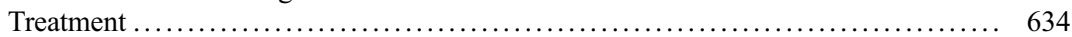

Clinical Course and Prognosis .......................................... 634

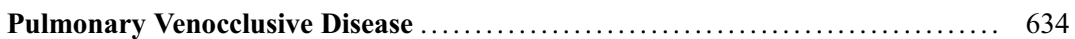

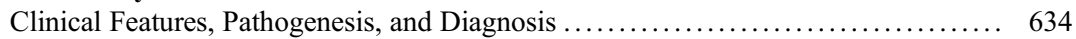

Treatment and Prognosis ......................................... 634

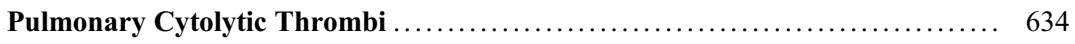

Pleuroparenchymal Fibroelastosis .................................... 635

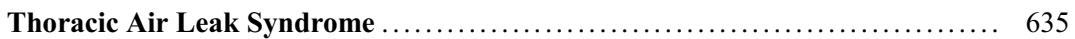

K. Dsouza · V. J. Thannickal $(\bowtie)$

Division of Pulmonary, Allergy and Critical Care

Medicine, Department of Medicine, University of

Alabama at Birmingham, Birmingham, AL, USA

e-mail:kdsouza@uabmc.edu; vthannickal@uabmc.edu

C. Pywell

Department of Medicine, University of Alabama at

Birmingham, Birmingham, AL, USA

e-mail: cameronpywell@uabmc.edu 
Post-transplant Lymphoproliferative Disorder $\ldots \ldots \ldots \ldots \ldots \ldots \ldots \ldots \ldots \ldots \ldots \ldots \ldots$

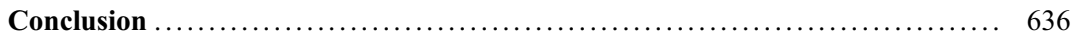

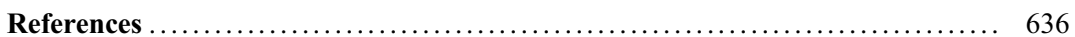

\section{Abstract}

Hematopoietic stem cell transplantation (HSCT) is an established therapeutic modality for a number of malignant and nonmalignant conditions. Pulmonary complications following HSCT are associated with increased mortality and morbidity. These complications may be classified into infectious versus noninfectious, and early versus late based on the time of occurrence post-transplant. Thus, exclusion of infectious etiologies is the first step in the diagnoses of pulmonary complications. Late onset noninfectious pulmonary complications typically occur 3 months posttransplant. Bronchiolitis obliterans is the major contributor to late-onset pulmonary complications, and its clinical presentation, pathogenesis, and current therapeutic approaches are discussed. Idiopathic pneumonia syndrome is another important complication which usually occurs early, although its onset may be delayed. Organizing pneumonia is important to recognize due to its responsiveness to corticosteroids. Other late onset noninfectious pulmonary complications discussed here include pulmonary venoocclusive disease, pulmonary cytolytic thrombi, pleuroparenchymal fibroelastosis, thoracic air leak syndrome, and posttransplant lymphoproliferative disorders.

\section{Keywords}

Bronchiolitis obliterans · Hematopoietic stem cell transplant $\cdot$ Pulmonary complications · Organizing pneumonia

\section{Introduction}

Hematopoietic stem cell transplantation (HSCT) is an established form of therapy for a number of malignant as well as nonmalignant conditions. More than 21,000 HSCTs were conducted in the
United States in 2016 (https://www.cibmtr.org). The two main types of HSCTs are autologous and allogenic. Autologous HSCT involves collection of stem cells from the patient that are then infused back after chemotherapy. Allogenic HSCT involves infusion of stem cells from a donor.

The morbidity and mortality from HSCTrelated complications have been on the decline over the past several years. These complications are broadly categorized based on etiology, namely, whether they are infectious or noninfectious, and the time of onset of such complications, early vs. late. Pulmonary complications are the most common life-threatening complications post HSCT occurring in 30-60\% of patients [1]. We define late onset complications are occurring 3 months after post-HSCT (Fig. 1). In this chapter, we discuss late noninfectious pulmonary complications in HSCT, and current concepts on their pathogenesis, diagnosis, and management. The primary focus will be on bronchiolitis obliterans (BO) which is the most common and carries the highest mortality of the late onset noninfectious complications [81]. The other late onset noninfectious complications that will be discussed include idiopathic pneumonia syndrome, organizing pneumonia, pulmonary venoocclusive disease, pulmonary cytolytic thrombi, pleuroparenchymal fibroelastosis, thoracic air leak syndrome, and posttransplant lymphoproliferative disorders.

\section{Bronchiolitis Obliterans}

BO typically occurs between 3 months to several years post HSCT and is inclusive of the spectrum of chronic graft versus host disease (cGVHD) $[29,60]$. BO is characterized by progressive, irreversible airway narrowing due to circumferential small airway fibrosis. There is limited understanding of $\mathrm{BO}$ pathogenesis. BO 


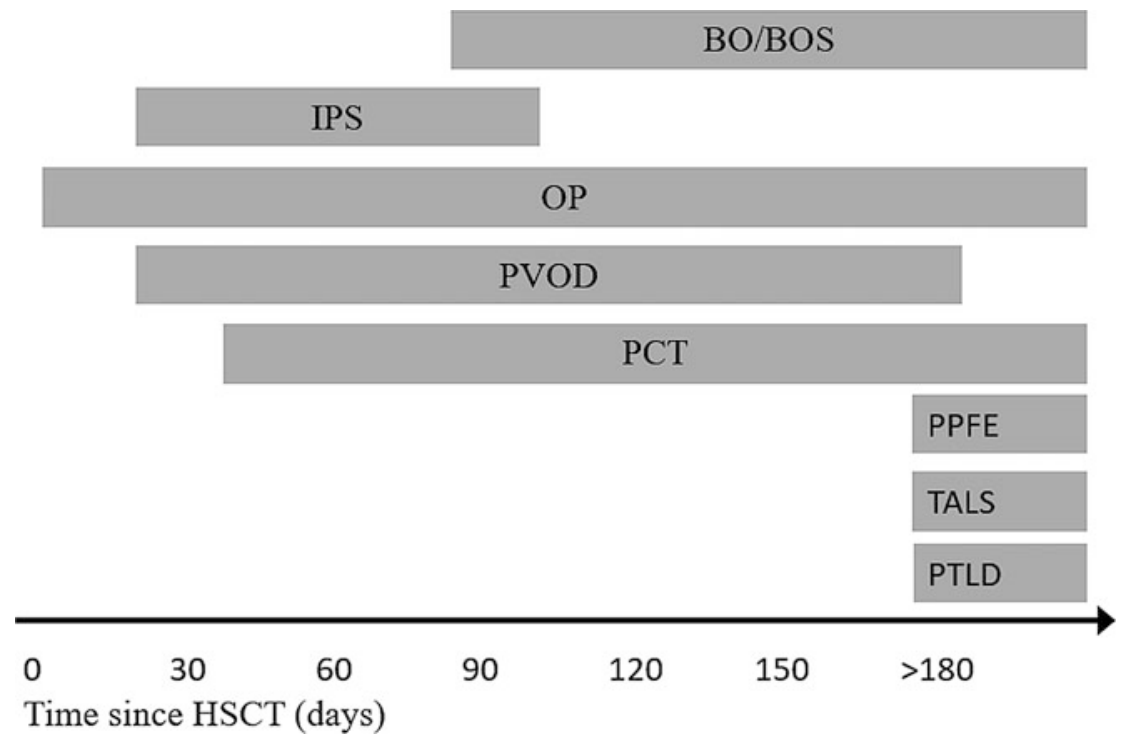

Fig. 1 Timeline of noninfectious HSCT pulmonary complications. BO/BOS bronchiolitis obliterans/bronchiolitis obliterans syndrome, IPS idiopathic pneumonia syndrome, $O P$ organizing pneumonia, $P V O D$ pulmonary

is a pathological diagnosis requiring invasive surgical lung biopsy, which is uncommonly performed in the clinical setting. BO syndrome (BOS) is a more useful clinical diagnosis that is made based on irreversible airflow limitation on pulmonary function testing (PFT) without the need for lung biopsy.

$\mathrm{BO}$ is the most common late onset noninfectious complication of HSCT. The reported incidence of $\mathrm{BO} / \mathrm{BOS}$ after allogeneic HSCT varies based on the diagnostic criteria used, ranging from $2 \%$ to $30 \%$ in retrospective studies [60]. A recent prospective study to evaluate the epidemiology of late non onset noninfectious complications after allogenic stem cell transplant reported a cumulative incidence of BOS 36 months posttransplant at $10.7 \%$ [9]. BO/BOS following autologous HSCT is rare but has been reported $[31,61]$.

\section{Clinical Features and Diagnosis}

Clinical features of $\mathrm{BO} / \mathrm{BOS}$ are nonspecific. In early stages of the disease, patients are venoocclusive disease, $P C T$ pulmonary cytolytic thrombi, $P P F E$ pleuroparenchymal fibroelastosis, TALS thoracic air leak syndrome, $P T L D$ post-transplant lymphoproliferative disorder

asymptomatic and are identified by airflow limitation on PFTs. Nonproductive cough, dyspnea on exertion, and decreased exercise tolerance are common [14]. Physical examination may be normal or reveal signs of airflow obstruction such as wheezing, hyperinflation, or diffuse crackles. Other causes of such presentations, in particular, respiratory infections, should be ruled out.

The chest radiograph may be normal or reveal hyperinflation. High resolution chest tomography (HRCT) reveals small airway involvement with features of air trapping evidenced by mosaic attenuation on expiratory views (Fig. 2). Histopathology, when available, shows narrowing or complete occlusion of the bronchiolar lumen due to subepithelial inflammatory fibrosis is a hallmark of BO (Fig. 3) [5]. Transbronchial biopsies are insufficient to yield a diagnosis and surgical lung biopsies often prohibitively expose patients to procedural risks. In most cases, BOS can be diagnosed without a histopathological diagnosis using PFTs in the appropriate clinical setting.

The updated National Institutes of Health (NIH) guidelines for diagnosing BOS are based on the following criteria [43]: 


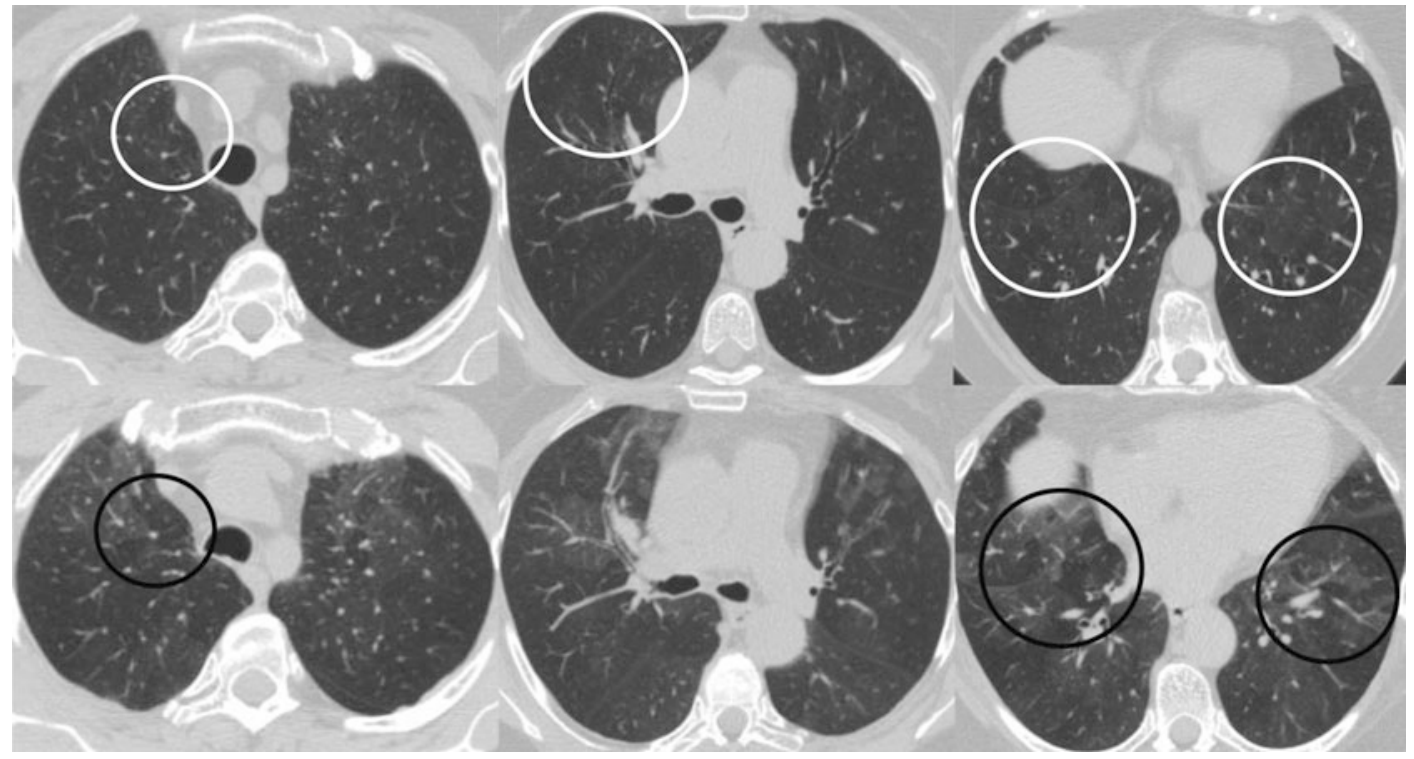

Fig. 2 62-year-old woman with history of allogenic bone marrow transplant for diffuse large B-cell lymphoma 2.5 years back. She presented with progressive shortness of breath. High Resolution Computed Tomography (HRCT) images in inspiration (top row) show subtle mosaic abnormalities (white circles) and the images in expiration (bottom row) show decreased attenuation of these areas (black circles), consistent with air trapping. This appearance is highly concerning for bronchiolitis obliterans syndrome in this setting. (Image courtesy: Dr. Sushilkumar Sonvane, MD - University of Alabama at Birmingham, Department of Radiology)

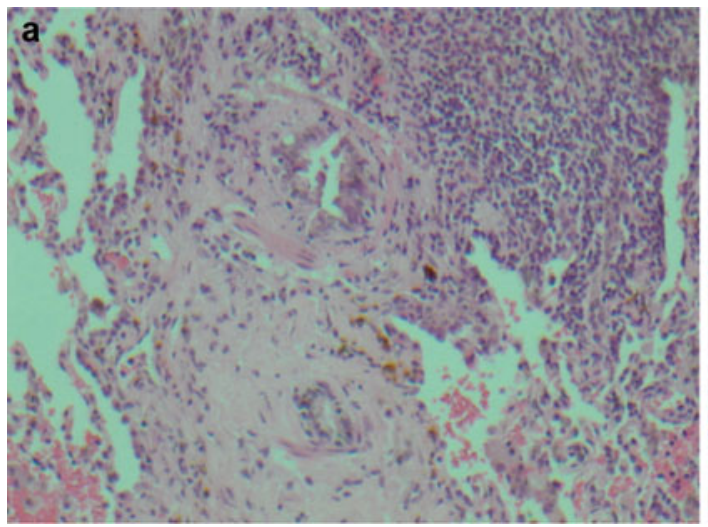

Fig. 3 High power view demonstrating early lesion in bronchiolitis obliterans (a) with peribronchial fibrosis and inflammation progressing to frank interalveolar

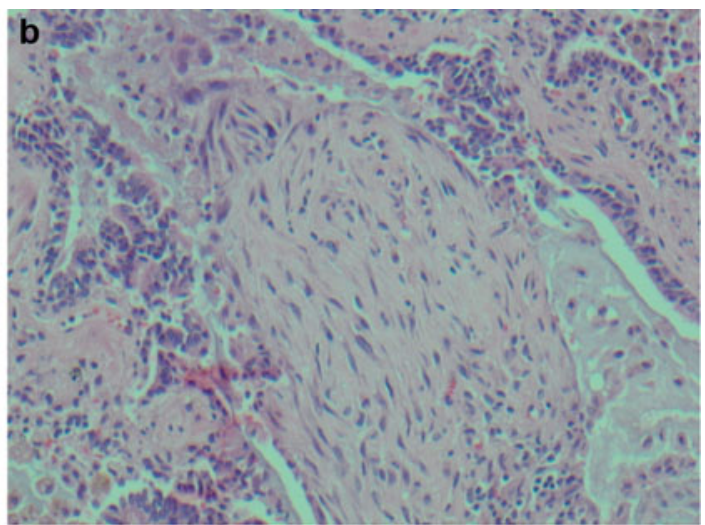

fibroblastic plug formation (b). (Image courtesy: Dr. David Ralph Crowe, MD - University of Alabama Birmingham, Department of Pathology)
1. Forced expiratory volume in one second (FEV1)/vital capacity $<0.7$ or the fifth percentile of predicted.

(a) Vital capacity includes forced vital capacity or slow vital capacity, whichever is greater. (b) The fifth percentile of predicted is the lower limit of the $90 \%$ confidence interval.

(c) For pediatric or elderly patients, use the lower limits of normal, defined according to National Health and Nutrition Examination Survey III calculations [36]. 
2. FEV $1<75 \%$ of predicted with $\geq 10 \%$ decline over less than 2 years. FEV1 should not correct to $>75 \%$ of predicted with albuterol, and the absolute decline for the corrected values should still remain at $\geq 10 \%$ over 2 years.

3. Absence of infection in the respiratory tract, documented with investigations directed by clinical symptoms, such as chest radiographs, computed tomographic (CT) scans, or microbiologic cultures (sinus aspiration, upper respiratory tract viral screen, sputum culture, bronchoalveolar lavage).

4. One of the two supporting features of BOS:

(a) Evidence of air trapping by expiratory CT or small airway thickening or bronchiectasis by high-resolution chest $\mathrm{CT}$ or

(b) Evidence of air trapping by PFTs: residual volume $>120 \%$ of predicted or residual volume/total lung capacity elevated outside the $90 \%$ confidence interval

It is important to recognize that a significant number of bronchioles must be involved to manifest airflow limitation on PFTs or to develop clinical symptoms. Hence, early stages of BO may be missed.

\section{Risk Factors and Pathogenesis}

Several risk factors for the development of BOS have been identified, and most of these are closely associated with the occurrence of cGVHD [98]. Increasing age of the donor/recipient, development of acute GVHD [26], ABO incompatibility [24], the presence of extra thoracic GVHD, low circulating $\mathrm{IgG}$, and non-Caucasian race [4] have been identified in several retrospective studies. Additional risk factors include the type of transplant procedure such a peripheral blood stem cell transplant [57] and busulfan-based conditioning regimens [69]. Use of antithymocyte globulin (ATG) as part of the pretransplant conditioning regimen is associated with a decreased incidence of BOS [22].

Prior to meeting established criteria for BOS, a decrease in FEV1 from pretransplant levels has also been identified to be a risk factor for the subsequent development of BOS [13]. More recently, a $10 \%$ decline in FEV1 from pretransplant to day 100 posttransplant has shown to be predictive for the development of BOS [9].

The precise pathogenetic mechanisms involved in the development of BO are unclear. The pathogenesis appears to be multifactorial and may involve diverse etiologies [5]. Airway epithelial injury is the inciting factor secondary to gastroesophageal reflux disease, respiratory infections, and chemotherapeutic drugs. This is typically followed by a dysregulated immune response that leads to the development of fibrotic changes in small airways. T cells and humoral mechanisms have been implicated [23, 76]. Genetic polymorphisms in NOD2/CARD15 have been linked to susceptibility to BOS [39].

\section{Treatment}

There are currently no effective treatments for BOS complicating HSCT. Most treatment protocols are based on combinations of immunosuppressive drugs and, until recently, were largely based on expert opinion. Traditionally, immunosuppression in the form of systemic steroids for extended periods has been used; alternatively, calcineurin inhibitors and azathioprine, agents that impair lymphocyte activation and proliferation, have been employed. Long-term, high-intensity immunosuppression is no longer recommended due to the increased risk of infections [91].

Most clinical studies of treatments for BOS are difficult to interpret due to small sample sizes, their retrospective nature, and confounding effects of treatment for cGVHD. These studies have included systemic corticosteroids [28, 65, 82], rituximab [10, 46], imatinib [59], etanercept [12, 95], as well as extracorporeal photopheresis [52]. A recent retrospective matched cohort study recently showed that extracorporeal photopheresis improves survival in HSCT patients with BOS [37].

Treatment with inhaled budesonide/formoterol led to significant FEV1 improvements in patients with mild/severe BOS after allogeneic HSCT [7]. Another trial showed FEV1 stabilization 
using a combination of fluticasone, azithromycin, and montelukast along with pulse dosed systemic steroids [92]. A randomized, double-blinded, placebo-controlled trial of azithromycin alone did not reveal any change in FEV1 in late BOS post HSCT [48]. Prophylactic azithromycin has been shown to prevent the onset of lung transplant-related BOS, as well as stabilize FEVI in post-lung transplant BOS $[19,88]$. However, prophylactic azithromycin has not shown to be effective in BOS post-HSCT in retrospective studies [44]. A prospective study on the prophylactic use of azithromycin to prevent airflow decline resulted in early termination secondary to hematological relapses [8]; an FDA warning was issued in August 2018 until further review (https://www.fda.gov/ Drugs/DrugSafety/ucm614085.htm). Prospective trials of azithromycin, bortezomib, inhaled cyclosporine, and neutrophil elastase inhibitors for prophylaxis and/or treatment of BOS are underway (www.clinicaltrials.gov).

Current treatment strategies include high-dose inhaled glucocorticoid with or without a long acting inhaled beta agonist based on symptoms, with close monitoring of lung function with PFTs. If progressive decline in FEV1 occurs with this regimen, initiation of a combination of fluticasone, azithromycin, and montelukast (FAM) therapy can be considered [91]. Occasionally, patients with chronic GVHD and refractory BOS may respond to increased immunosuppression. In patients who progress despite medical therapies, lung transplantation may be the only option $[40,86]$.

Novel therapeutic approaches for $\mathrm{BO} / \mathrm{BOS}$ are currently being investigated. The pleiotropic small molecule p38 MAK inhibitor, pirfenidone, has been shown to ameliorate $\mathrm{BO}$ in a murine model of cGVHD [25]. An early phase clinical study evaluating the safety and tolerability of pirfenidone in BOS is currently underway (www.clinicaltrials.gov; NCT03315741).

\section{Clinical Course and Prognosis}

The clinical course of BOS is variable, with some patients experiencing rapid declines in lung function, while others stabilize or improve. Mortality from BOS is most commonly due to progressive respiratory failure. BOS confers a 1.6 fold increased risk of death after diagnosis [4]. Early onset of BOS and lower FVC, especially within a year of transplant, is associated with a worse prognosis $[13,26]$. Recent estimates indicate a 2-3 year survival of $60-75 \%$, and a 5 -year survival of $40-50 \%$; this is an improvement in overall survival from a decade ago, when 2-year survival was $40 \%$, and 5 -year survival was $20 \%$. Early recognition, newer treatment strategies, and better supportive care likely account for this improved survival [91].

\section{Idiopathic Pneumonia Syndrome}

Idiopathic pneumonia syndrome (IPS) is a severe noninfectious complication of HSCT with an incidence of $12 \%$ when it was first described in the $1990 \mathrm{~s}$; more recently, incidence is cited at $3-15 \%$ $[14,60]$. IPS is more common as an early complication of HSCT but can occur after 3 months. Median time of onset is 19 days posttransplant, with a range from 4 to 106 days [60]. IPS is an acute lung injury process characterized by diffuse alveolar damage in the absence of an identifiable lower respiratory tract infection.

\section{Pathogenesis and Risk Factors}

Although the exact cause of IPS remains unknown, immune involvement has been invoked; murine models involving immune mismatches between donor and recipient support this concept $[15,73]$. Elevated levels of lipopolysaccharide (LPS) and tumor necrosis factor-alpha (TNF- $\alpha$ ) have been observed in BAL samples of murine IPS models [16]. TNF- $\alpha$ may contribute to pathogenesis by direct toxicity, upregulation of major histocompatibility complex (MHC), increased leukocyte recruitment, and cellmediated apoptosis [60]. Donor T lymphocytes secrete chemokines which further amplify the inflammatory cascade [38]. Decreased level of pulmonary surfactant has also been associated with IPS development [27, 56, 94]. 
Risk factors for IPS include full-intensity conditioning regimens such as total body irradiation and busulfan, acute GVHD, advanced age, and underlying acute leukemia and myelodysplastic syndrome (MDS) [33, 68, 90]. Reduced-intensity conditioning regimens have decreased the incidence of IPS [33]. In children, risk factors for IPS include the underlying disease and busulfan-based conditioning regimens [66]. Interestingly, risk of IPS increases with the number of platelet transfusions received, though the transfusion requirement could be a marker of disease severity $[84,85]$.

\section{Clinical Features and Diagnosis}

The definition of IPS, updated in the 2011 American Thoracic Society guidelines, is based on the following criteria [60]:

1. Evidence of widespread alveolar injury

(a) Multilobar infiltrates on routine chest radiographs or computed tomography

(b) Symptoms and signs of pneumonia (cough, dyspnea, tachypnea, rales)

(c) Evidence of abnormal pulmonary physiology

(i) Increased alveolar to arterial oxygen difference

(ii) New or increased restrictive pulmonary function test abnormality

2. Absence of active lower respiratory tract infection based upon:

(a) Bronchoalveolar lavage negative for significant bacterial pathogens including acid-fast bacilli, Nocardia, and Legionella species

(b) Bronchoalveolar lavage negative for pathogenic nonbacterial microorganisms:

(i) Routine culture for viruses and fungi

(ii) Shell vial culture for CMV and respiratory RSV

(iii) Cytology for CMV inclusions, fungi, and Pneumocystis jirovecii (carinii)

(iv) Direct fluorescence staining with antibodies against CMV, RSV, HSV, VZV, influenza virus, parainfluenza virus, adenovirus, and other organisms (c) Other organisms/tests to also consider:

(i) Polymerase chain reaction for human metapneumovirus, rhinovirus, coronavirus, and HHV6

(ii) Polymerase chain reaction for Chlamydia, Mycoplasma, and Aspergillus species

(iii) Serum galactomannan ELISA for Aspergillus species

(d) Transbronchial biopsy if condition of the patient permits

3. Absence of cardiac dysfunction, acute renal failure, or iatrogenic fluid overload as etiology for pulmonary dysfunction

Radiographic findings can be nonspecific, but HRCT findings include ground glass opacities that are bilateral, central, symmetric, with consolidation seen in more severe cases [75]. Recent advances in diagnostic capabilities have increased detection of occult infections which help separate IPS from infectious HSCT complications; the distinction is critical due to their vastly distinct treatment approaches. Many patients diagnosed with IPS were later discovered to have detectable pathogens, most commonly HHV-6, human rhinovirus, and aspergillus, when their BAL samples were re-examined [72].

\section{Treatment}

Historically, treatment of IPS has been largely supportive. Once infections have been ruled out, systemic corticosteroids are the mainstay of treatment; IPS in association with diffuse alveolar hemorrhage may require higher doses [60]. The results of other immunotherapeutic agents such as the soluble TNF- $\alpha$ inhibitor, etanercept, has been mixed. A retrospective single-center study over two distinct timeperiods comparing steroids alone (earlier timeperiod) versus combined steroids and etanercept showed significant improvement in survival to hospital discharge [80]. However, the more recent use of reduced-intensity conditioning regimens and improved supportive care may have accounted for this improvement. Patients 
with late-onset IPS who responded to etanercept have greatly improved short- and long-term mortality [79]. Results in children have been similarly promising, with complete response in $20 \%$ of patients [97]. A randomized, doubleblind, placebo-controlled trial comparing corticosteroids with placebo to corticosteroids with etanercept was inconclusive due to slow patient accrual and early termination [96]. Other potential therapies are under investigation. Blockade of NF- $\mathrm{KB}$, a transcription factor downstream of the TNF- $\alpha$ receptor, has shown promise in murine models [30]. Pulmonary surfactant replacement is also being studied as an intervention to treat IPS [60].

\section{Clinical Course and Prognosis}

Outcomes for IPS remain poor, with mortality rates between $60 \%$ and $80 \%$. Rapid clinical deterioration can occur and $>95 \%$ of patients requiring mechanical ventilation succumb to the disease [20, 33, 45]. Veno-venous extracorporeal membrane oxygenation (ECMO) as a rescue therapy or bridge-to-recovery has met with mixed results $[47,51]$. Short-term survival has improved with treatment advances, but 2-year survival remains low. Based on a small study, a more rapid peak and decline in severity of infiltrates on HRCT has been linked to a more favorable prognosis [75]. Biomarkers to predict patients who at risk for IPS and who respond to biologic therapy are being studied [71].

\section{Organizing Pneumonia}

Organizing Pneumonia (OP), formerly known as bronchiolitis organizing pneumonia (BOOP), is a complication of HSCT. It can occur as a part of the IPS spectrum or as a stand-alone late onset pulmonary complication of HSCT [6]. OP as a complication of HSCT was first described by Thirman et al. in 1992 [78]. Although it has been described as a complication of both autologous and allogenic HSCT, it is more common following the latter. The incidence of OP post-allogenic HSCT ranges from $0.9 \%$ to $10.3 \%$ with a median time of onset post-HSCT of 108 days [74]. Among 5340 patients, who underwent allogenic HSCT, 49 cases of histological BOOP/OP was reported, an incidence of $0.9 \%$ [32].

\section{Clinical Features and Diagnosis}

OP presents with fever, nonproductive cough, and dyspnea and can be precipitated by a recent taper of immunosuppressive regimen. PFTs commonly reveal a restrictive pattern, but could be normal, obstructive, or mixed with a decreased diffusion capacity of carbon monoxide (DLCO) [32, 58]. High resolution chest tomographic scans in patients with OP are notable for airspace consolidations, ground glass opacities, and nodular opacities (Fig. 4) [50]. In a study of 16 patients with biopsy-proven OP post-HSCT, ground glass opacities were noted to be the most common radiological feature [63]. Bronchoalveolar lavage is useful to exclude infections. Surgical lung biopsy is the gold standard for diagnosis of OP, as transbronchial biopsies have lower yield; however, the latter approach may be useful in certain clinical settings [2, 64]. Histopathological features on biopsy include presence of the buds of granulation tissue which contain myofibroblasts and a loose connective tissue (Fig. 5). These buds are intra-alveolar and can extend into the bronchioles causing obstruction with associated mild interstitial inflammation [18].

\section{Risk Factors and Pathogenesis}

A prior history of acute or chronic GVHD was found to be a strong risk factor for OP [32] and suggests a common pathogenesis. In a study of 9550 patients of post-allogenic HCST recipients, HLA disparity, female-to-male HSCT, and peripheral blood stem cell transplant (PBSCT) were associated with an increased risk of developing OP. In contrast, busulfan-based or fludarabine-based reduced-intensity conditioning compared to total body irradiation and $\mathrm{T}$ cell depletion regimens were associated with a lower risk [58]. The precise 


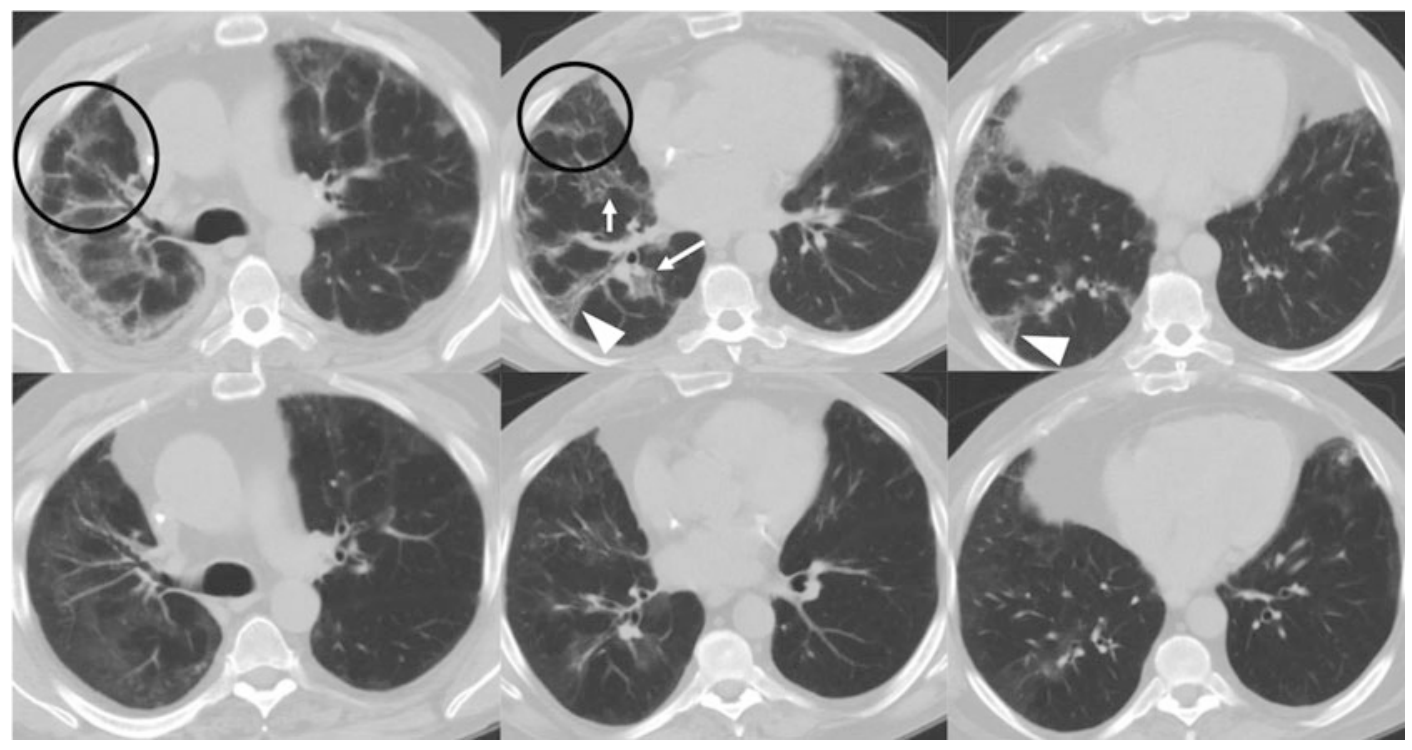

Fig. 4 69-year-old man with history of bone marrow transplant for AML a few years back. He presented with cough and increased shortness of breath. Noncontrast Computed Tomography (CT) of chest (top row) showed patchy consolidations scattered in peribronchiolar (arrow), perilobular distribution (circle), and peripheral, wedge shaped distribution (arrowhead) that were concerning for atypical infection or organizing pneumonia. The patient underwent bronchoscopy with biopsy. No infectious etiology was identified and a provisional diagnosis of cryptogenic organizing pneumonia was made. Patient was started on steroids and showed symptomatic improvement. Follow-up chest CT scan performed after 2 months (bottom row) showed marked improvement in parenchymal consolidations. (Image courtesy: Dr. Sushilkumar Sonvane, MD - University of Alabama at Birmingham, Department of Radiology)

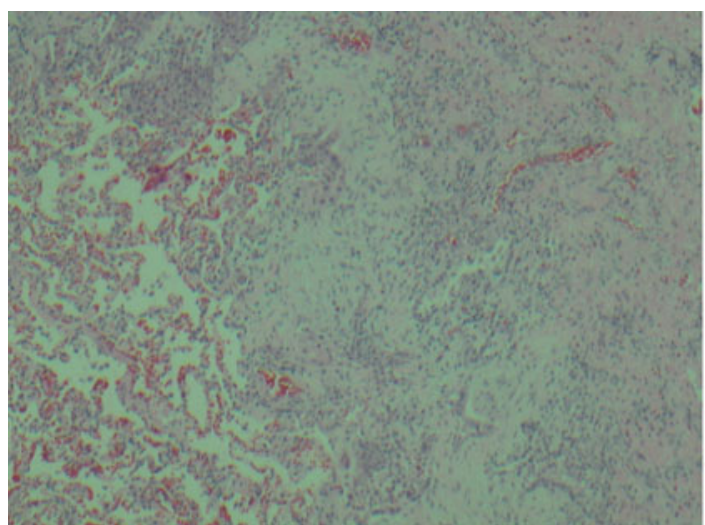

Fig. 5 OP demonstrating fibroblastic plugs are interalveolar at first and are then incorporated into alveolar septa before being resorbed. (Image courtesy: Dr. David

pathogenetic mechanisms of post-HSCT OP are unclear. The association with GVHD and increased incidence post-allogeneic HSCT suggests alloimmune-mediated lung injury. Murine models

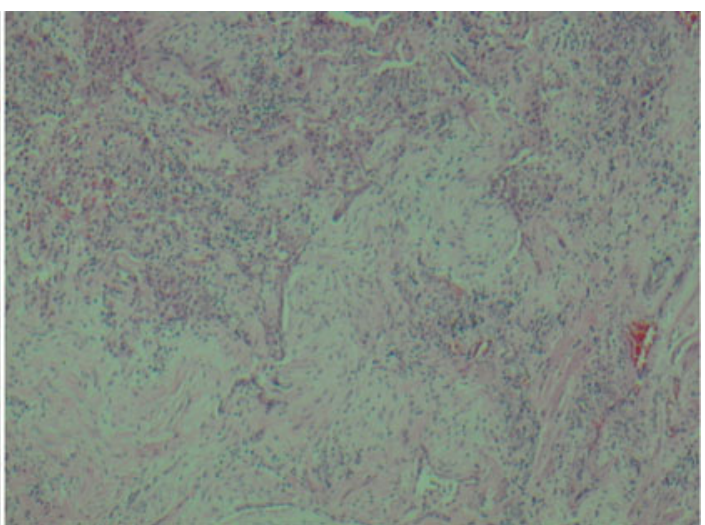

Ralph Crowe, MD - University of Alabama at Birmingham, Department of Pathology)

of OP after respiratory reovirus infections have demonstrated the role of $\mathrm{T}$ cells and cytokines such as interferon- $\alpha$ in the development of the process [53]. 


\section{Treatment}

HSCT-associated OP, as in most other cases of $\mathrm{OP}$, is primarily treated with high-dose systemic corticosteroids. There are no specific guidelines on the dose and duration of steroid therapy. Current recommendations are based on expert opinion, and clinical judgment should be exercised. Prednisone in doses ranging from $0.75-1.5 \mathrm{mg} / \mathrm{kg} /$ day have been used for 1-3 months with a slow taper over 6-12 months [17]. Further studies are needed to establish ideal doses and duration of corticosteroid therapy. Erythromycin in combination with corticosteroids has been reported with favorable outcomes [42], although the role of macrolides for treatment of OP is unclear.

\section{Clinical Course and Prognosis}

About $80 \%$ of patients with HSCT-associated OP have a favorable prognosis with resolution or stabilization after corticosteroid therapy [1]. Clinical improvement is seen usually within a week of starting therapy followed by radiological improvement. Failure to respond to treatment may result in progressive respiratory failure and death [32].

\section{Pulmonary Venocclusive Disease}

Pulmonary venoocclusive disease (PVOD) resulting in pulmonary hypertension is a rare late onset complication of both autologous and allogeneic HSCT [98]. In reported cases, it was noted in patients less than 25 years old and presented several weeks to months posttransplant [11].

\section{Clinical Features, Pathogenesis, and Diagnosis}

Presenting complaints are usually nonspecific, primarily fatigue and exertional dyspnea. Physical examination findings are similar to those of pulmonary hypertension which may be normal in early stages and become more apparent in later stages: Elevated JVD, peripheral edema, and hepatomegaly. Elevated second heart sound, parasternal lift and palpable second heart sounds in the second left intercostal space can be recognized in some patients along with tricuspid regurgitation murmur. Computed tomographic (CT) scans of the chest may show septal thickening, diffuse or mosaic ground glass opacities, small nodules, and areas of consolidation. Right heart catheterization reveals an increased pulmonary artery pressure and normal pulmonary capillary pressure. The triad of severe pulmonary hypertension in the setting of normal pulmonary artery occlusion pressure and radiographic evidence of pulmonary edema could be suggestive of PVOD but is not diagnostic. PVOD can be definitively diagnosed only by surgical biopsy and is characterized by the progressive intimal proliferation, fibrosis, and occlusion of the pulmonary venules as well as small veins [54]. The pathogenesis of PVOD post HSCT is unclear and has been attributed to toxic endothelial injury secondary to chemotherapeutic conditioning regimens and/or viral infections [74] but does not seem to be associated with cGVHD [6].

\section{Treatment and Prognosis}

There are no effective treatments for PVOD and prognosis is poor. Conventional arterial vasodilator therapy for pulmonary hypertension could worsen pulmonary edema in PVOD and if initiated should be done with close monitoring [11, 74]. Reported cases of PVOD post HSCT have shown some favorable response to steroid therapy $[11,35,41]$.

\section{Pulmonary Cytolytic Thrombi}

Pulmonary cytolytic thrombi (PCT) is a complication of allogenic HSCT and primarily occurs in children with GVHD [93]. The incidence is between $1.2 \%$ and $4 \%$ with a median onset of 3 months post HSCT [83]. Patients typically present with fever, cough, and dyspnea. CT scans of the chest shows peripheral pulmonary and pleural 
nodules [93]. Bronchoalveolar lavage is indicated to exclude infectious etiology. The diagnosis of PCT is based on surgical biopsy of the lung nodules which are characterized by vascular occlusive and hemorrhagic infarcts secondary to thrombi containing intensely basophilic amorphous material as well as entrapped leucocytes [34]. The prognosis of PCT is favorable as it responds to treatment with systemic corticosteroids. There has not been any mortality attributed to PCT in the reported literature.

\section{Pleuroparenchymal Fibroelastosis}

Pleuroparenchymal fibroelastosis (PPFE) is a rare complication of HSCT, grouped under rare interstitial pneumonias with a prevalence of around $0.3 \%$ in HSCT recipients [55]. It is characterized by progressive sub pleural fibrosis predominantly in the upper lobes. PPFE has been reported post allogeneic and autologous HSCT. The etiology of PPFE post HSCT is unclear. Chemotherapeutic drugs, radiation therapy and a possible association with cGVHD have been hypothesized [87] to be predisposing factors.

Patients can present with dry cough, exertional dyspnea, and chest pain secondary to spontaneous pneumothorax [89]. PFTs reveal a restrictive or mixed picture of obstruction and restriction. CT scan is characteristic of pleural thickening, fibrosis, subpleural reticulations, and traction bronchiectasis predominantly in the upper lobes [55]. Histopathological exam reveals alveolar collapse, subpleural fibrosis, and extensive elastic deposition [87]. The disease is progressive with worsening symptoms and poor prognosis. Currently no therapeutic options are available except for lung transplantation [6].

\section{Thoracic Air Leak Syndrome}

Thoracic air leak syndrome (TALS) consists of a spectrum of conditions that includes spontaneous pneumothorax, subcutaneous emphysema, pneumomediastinum, interstitial emphysema, and pneumopericardium. It occurs as a late onset complication of allogenic HSCT and is associated with cGVHD. According to reported literature, prevalence of TALS post allogenic HSCT is reported to be $0.83-5.7 \%$ with a median time range of 202-575 days post HSCT [6]. The mechanism of air leak in BOS is secondary to increased intra-alveolar pressure leading to alveolar rupture into the pulmonary interstitium with subsequent retrograde dissection of air into the mediastinum and subcutaneous tissue causing pneumomediastinum and subcutaneous emphysema. Similarly, rupture into the pleural space causes pneumothorax [62]. CT scan of the chest is the imaging modality of choice and can detect air in the pleural space, mediastinum, and subcutaneous tissue. Infections, cough, emesis, and other causes of a similar presentation should be ruled out. Prognosis is poor with 1-year and 3-year survival of $45 \%$ and $15 \%$, respectively [67].

\section{Post-transplant Lymphoproliferative Disorder}

Post-transplant lymphoproliferative disorder (PTLD) is a rare complication following allogeneic HSCT and has a cumulative incidence of $1 \%$ [21]. In a study of 21,686 HSCT patients' risk factors such as unrelated or HLA mismatched donors, use of ATG or monoclonal antibodies against $\mathrm{T}$ cells for GVHD prophylaxis or treatment, $\mathrm{T}$ cell depleted donor marrow, age $>50$ years and second HSCT were identified. The incidence of PTLD ranged from $0.2 \%$ in patients with no risk factors to more than $8 \%$ with more than 3 risk factors [49]. The pathogenesis of post HSCT PTLD is attributed to proliferation of donor Epstein-Barr Virus (EBV) infected $\mathrm{B}$ cells in the setting of weakened T-cell immunity. Though post HSCT is common in the lymph nodes, spleen, and liver, pulmonary involvement occurs in about $20 \%$ of the cases. Median onset is around 4-6 months post HSCT [3]. Clinical presentation varies and could range from asymptomatic to fulminant tumor lysis syndrome. CT scans of the chest are notable for multiple pulmonary nodules with basal and peripheral predominance, mediastinal and hilar lymphadenopathy, patchy 
consolidation, pleural effusion, and chest wall or pleural-based masses [70]. Diagnosis may require a biopsy or could be made via noninvasive methods in the appropriate clinical setting. A probable diagnosis is made by increased EBV DNA levels in the setting of lymphadenopathy or hepatosplenomegaly and when other causes have been ruled out, proven disease requires a biopsy. Treatment strategies include rituximab, reduction of immunosuppression, donor lymphocyte infusion, chemotherapy, and EBV-specific cytotoxic $\mathrm{T}$ lymphocyte infusions [77]. The prognosis of PTLD post HSCT is poor compared to that occurring after solid organ transplantation [62].

\section{Conclusion}

Late onset pulmonary complications following HSCT are a major cause of mortality and morbidity. Advances in transplant techniques, earlier diagnosis, prevention, and management of infectious complications have led to better outcomes as well as shifted the focus to late noninfectious pulmonary complications in HSCT. These complications are myriad and require further studies to develop more effective screening, preventative, and treatment strategies.

\section{References}

1. Afessa B, Peters SG. Major complications following hematopoietic stem cell transplantation. Semin Respir Crit Care Med. 2006;27(3):297-309. https://doi.org/ 10.1055/s-2006-945530.

2. Alasaly K, Muller N, Ostrow DN, Champion P, FitzGerald JM. Cryptogenic organizing pneumonia. A report of 25 cases and a review of the literature. Medicine (Baltimore). 1995;74(4):201-11.

3. Al-Mansour Z, Nelson BP, Evens AM. Post-transplant lymphoproliferative disease (PTLD): risk factors, diagnosis, and current treatment strategies. Curr Hematol Malig Rep. 2013;8(3):173-83. https://doi.org/10.1007/ s11899-013-0162-5.

4. Au BK, Au MA, Chien JW. Bronchiolitis obliterans syndrome epidemiology after allogeneic hematopoietic cell transplantation. Biol Blood Marrow Transplant. 2011;17(7):1072-8. https://doi.org/10.1016/j.bbmt. 2010.11.018
5. Barker AF, Bergeron A, Rom WN, Hertz MI. Obliterative bronchiolitis. N Engl J Med. 2014;370(19): 1820-8. https://doi.org/10.1056/NEJMra1204664.

6. Bergeron A. Late-onset noninfectious pulmonary complications after allogeneic hematopoietic stem cell transplantation. Clin Chest Med. 2017;38(2):249-62. https://doi.org/10.1016/j.ccm.2016.12.013.

7. Bergeron A, Chevret S, Chagnon K, Godet C, Bergot E, Peffault de Latour R, Dominique S, de Revel T, Juvin K, Maillard N, Reman O, Contentin N, Robin M, Buzyn A, Socie G, Tazi A. Budesonide/formoterol for bronchiolitis obliterans after hematopoietic stem cell transplantation. Am J Respir Crit Care Med. 2015;191(11):1242-9. https:// doi.org/10.1164/rccm.201410-1818OC.

8. Bergeron A, Chevret S, Granata A, Chevallier P, Vincent L, Huynh A, Tabrizi R, Labussiere-Wallet H, Bernard M, Chantepie S, Bay JO, Thiebaut-Bertrand A, Thepot S, Contentin N, Fornecker LM, Maillard N, Risso K, Berceanu A, Blaise D, Peffault de La Tour R, Chien JW, Coiteux V, Socie G, ALLOZITHRO Study Investigators. Effect of azithromycin on airflow decline-free survival after allogeneic hematopoietic stem cell transplant: the ALLOZITHRO randomized clinical trial. JAMA. 2017;318(6):557-66. https://doi. org/10.1001/jama.2017.9938.

9. Bergeron A, Chevret S, Peffault de Latour R, Chagnon K, de Margerie-Mellon C, Riviere F, Robin M, Mani J, Lorillon G, Socie G, Tazi A. Noninfectious lung complications after allogeneic haematopoietic stem cell transplantation. Eur Respir J. 2018;51(5). https://doi.org/10.1183/13993 003.02617-2017.

10. Brownback KR, Thomas LA, McGuirk JP, Ganguly S, Streiler C, Abhyankar S. Effect of rituximab on pulmonary function in bronchiolitis obliterans syndrome due to graft-versus-host-disease. Lung. 2017;195(6): 781-8. https://doi.org/10.1007/s00408-017-0051-0.

11. Bunte MC, Patnaik MM, Pritzker MR, Burns LJ. Pulmonary veno-occlusive disease following hematopoietic stem cell transplantation: a rare model of endothelial dysfunction. Bone Marrow Transplant. 2008;41(8):677-86. https://doi.org/10.1038/sj.bmt.17 05990.

12. Busca A, Locatelli F, Marmont F, Ceretto C, Falda M. Recombinant human soluble tumor necrosis factor receptor fusion protein as treatment for steroid refractory graft-versus-host disease following allogeneic hematopoietic stem cell transplantation. Am J Hematol. 2007;82(1):45-52. https://doi.org/10.1002/ ajh. 20752 .

13. Cheng GS, Storer B, Chien JW, Jagasia M, Hubbard JJ, Burns L, Ho VT, Pidala J, Palmer J, Johnston L, Mayer S, Crothers K, Pusic I, Lee SJ, Williams KM. Lung function trajectory in bronchiolitis obliterans syndrome after allogeneic hematopoietic cell transplant. Ann Am Thorac Soc. 2016;13(11):1932-9. https://doi.org/10.1513/AnnalsATS.201604-262OC.

14. Clark JG, Crawford SW, Madtes DK, Sullivan KM. Obstructive lung disease after allogeneic marrow 
transplantation. Clinical presentation and course. Ann Intern Med. 1989;111(5):368-76.

15. Cooke KR, Kobzik L, Martin TR, Brewer J, Delmonte J Jr, Crawford JM, Ferrara JL. An experimental model of idiopathic pneumonia syndrome after bone marrow transplantation: I. The roles of minor $\mathrm{H}$ antigens and endotoxin. Blood. 1996;88(8):3230-9.

16. Cooke KR, Hill GR, Gerbitz A, Kobzik L, Martin TR, Crawford JM, Brewer JP, Ferrara JL. Tumor necrosis factor-alpha neutralization reduces lung injury after experimental allogeneic bone marrow transplantation. Transplantation. 2000;70(2):272-9.

17. Cordier JF. Organising pneumonia. Thorax. 2000;55(4):318-28.

18. Cordier JF. Cryptogenic organising pneumonia. Eur Respir J. 2006;28(2):422-46. https://doi.org/10.1183/ 09031936.06 .00013505$.

19. Corris PA, Ryan VA, Small T, Lordan J, Fisher AJ, Meachery G, Johnson G, Ward C. A randomised controlled trial of azithromycin therapy in bronchiolitis obliterans syndrome (BOS) post lung transplantation. Thorax. 2015;70(5):442-50. https://doi.org/10.1136/ thoraxjnl-2014-205998.

20. Crawford SW, Hackman RC. Clinical course of idiopathic pneumonia after bone marrow transplantation. Am Rev Respir Dis. 1993;147(6 Pt 1):1393-400. https://doi.org/10.1164/ajrccm/147.6_Pt_1.1393.

21. Curtis RE, Travis LB, Rowlings PA, Socie G, Kingma DW, Banks PM, Jaffe ES, Sale GE, Horowitz MM, Witherspoon RP, Shriner DA, Weisdorf DJ, Kolb HJ, Sullivan KM, Sobocinski KA, Gale RP, Hoover RN, Fraumeni JF Jr, Deeg HJ. Risk of lymphoproliferative disorders after bone marrow transplantation: a multi-institutional study. Blood. 1999;94(7):2208-16.

22. Dirou S, Malard F, Chambellan A, Chevallier P, Germaud P, Guillaume T, Delaunay J, Moreau P, Delasalle B, Lemarchand P, Mohty M. Stable longterm pulmonary function after fludarabine, antithymocyte globulin and i.v. BU for reduced-intensity conditioning allogeneic SCT. Bone Marrow Transplant. 2014;49(5):622-7. https://doi.org/10.1038/bmt. 2014.15.

23. Ditschkowski M, Elmaagacli AH, Trenschel R, Peceny R, Koldehoff M, Schulte C, Beelen DW. T-cell depletion prevents from bronchiolitis obliterans and bronchiolitis obliterans with organizing pneumonia after allogeneic hematopoietic stem cell transplantation with related donors. Haematologica. 2007;92(4): 558-61.

24. Ditschkowski M, Elmaagacli AH, Koldehoff M, Gromke T, Trenschel R, Beelen DW. Bronchiolitis obliterans after allogeneic hematopoietic SCT: further insight-new perspectives? Bone Marrow Transplant. 2013;48(9):1224-9. https://doi.org/10.1038/bmt.2013.17.

25. Du J, Paz K, Flynn R, Vulic A, Robinson TM, Lineburg KE, Alexander KA, Meng J, Roy S, Panoskaltsis-Mortari A, Loschi M, Hill GR, Serody JS, Maillard I, Miklos D, Koreth J, Cutler CS,
Antin JH, Ritz J, MacDonald KP, Schacker TW, Luznik L, Blazar BR. Pirfenidone ameliorates murine chronic GVHD through inhibition of macrophage infiltration and TGF-beta production. Blood. 2017;129(18):2570-80. https://doi.org/10.1182/blood2017-01-758854.

26. Dudek AZ, Mahaseth H, DeFor TE, Weisdorf DJ. Bronchiolitis obliterans in chronic graft-versus-host disease: analysis of risk factors and treatment outcomes. Biol Blood Marrow Transplant. 2003;9(10): 657-66. https://doi.org/10.1016/S1083.

27. Epaud R, Ikegami M, Whitsett JA, Jobe AH, Weaver TE, Akinbi HT. Surfactant protein B inhibits endotoxin-induced lung inflammation. Am J Respir Cell Mol Biol. 2003;28(3):373-8. https://doi.org/ 10.1165/rcmb.2002-00710C.

28. Even-Or E, Ghandourah H, Ali M, Krueger J, Sweezey NB, Schechter T. Efficacy of high-dose steroids for bronchiolitis obliterans syndrome post pediatric hematopoietic stem cell transplantation. Pediatr Transplant. 2018;22(2). https://doi.org/10.1111/petr. 13155.

29. Filipovich AH, Weisdorf D, Pavletic S, Socie G, Wingard JR, Lee SJ, Martin P, Chien J, Przepiorka D, Couriel D, Cowen EW, Dinndorf P, Farrell A, Hartzman R, Henslee-Downey J, Jacobsohn D, McDonald G, Mittleman B, Rizzo JD, Robinson M, Schubert M, Schultz K, Shulman H, Turner M, Vogelsang G, Flowers ME. National Institutes of Health consensus development project on criteria for clinical trials in chronic graft-versus-host disease: I. Diagnosis and staging working group report. Biol Blood Marrow Transplant. 2005;11(12):945-56. https://doi.org/10.1016/j.bbmt.2005.09.004.

30. Fowler KA, Jania CM, Tilley SL, PanoskaltsisMortari A, Baldwin AS, Serody JS, Coghill JM. Targeting the canonical nuclear factor-kappaB pathway with a high-potency IKK2 inhibitor improves outcomes in a mouse model of idiopathic pneumonia syndrome. Biol Blood Marrow Transplant. 2017;23(4):569-80. https://doi.org/10.1016/j.bbmt. 2017.01.083.

31. Frankovich J, Donaldson SS, Lee Y, Wong RM, Amylon M, Verneris MR. High-dose therapy and autologous hematopoietic cell transplantation in children with primary refractory and relapsed Hodgkin's disease: atopy predicts idiopathic diffuse lung injury syndromes. Biol Blood Marrow Transplant. 2001;7(1):49-57. https://doi.org/10.1053/bbmt.2001. v7.pm11215699.

32. Freudenberger TD, Madtes DK, Curtis JR, Cummings P, Storer BE, Hackman RC. Association between acute and chronic graft-versus-host disease and bronchiolitis obliterans organizing pneumonia in recipients of hematopoietic stem cell transplants. Blood. 2003;102(10):3822-8. https://doi.org/10.1182/ blood-2002-06-1813.

33. Fukuda T, Hackman RC, Guthrie KA, Sandmaier BM, Boeckh M, Maris MB, Maloney DG, Deeg HJ, 
Martin PJ, Storb RF, Madtes DK. Risks and outcomes of idiopathic pneumonia syndrome after nonmyeloablative and conventional conditioning regimens for allogeneic hematopoietic stem cell transplantation. Blood. 2003;102(8):2777-85. https://doi.org/10.1182/ blood-2003-05-1597.

34. Gulbahce HE, Manivel JC, Jessurun J. Pulmonary cytolytic thrombi: a previously unrecognized complication of bone marrow transplantation. Am J Surg Pathol. 2000;24(8):1147-52.

35. Hackman RC, Madtes DK, Petersen FB, Clark JG. Pulmonary venoocclusive disease following bone marrow transplantation. Transplantation. 1989;47(6): 989-92.

36. Hankinson JL, Odencrantz JR, Fedan KB. Spirometric reference values from a sample of the general U.S. population. Am J Respir Crit Care Med. 1999;159(1):179-87. https://doi.org/10.1164/ajrccm. 159.1.9712108.

37. Hefazi M, Langer KJ, Khera N, Adamski J, Roy V, Winters JL, Gastineau DA, Jacob EK, Kreuter JD, Gandhi MJ, Hogan WJ, Litzow MR, Hashmi SK, Yadav H, Iyer VN, Scott JP, Wylam ME, CartinCeba R, Patnaik MM. Extracorporeal photopheresis improves survival in hematopoietic cell transplant patients with bronchiolitis obliterans syndrome without significantly impacting measured pulmonary functions. Biol Blood Marrow Transplant. 2018. https://doi. org/10.1016/j.bbmt.2018.04.012.

38. Hildebrandt GC, Corrion LA, Olkiewicz KM, Lu B, Lowler K, Duffner UA, Moore BB, Kuziel WA, Liu C, Cooke KR. Blockade of CXCR3 receptor: ligand interactions reduces leukocyte recruitment to the lung and the severity of experimental idiopathic pneumonia syndrome. J Immunol. 2004;173(3):2050-9.

39. Hildebrandt GC, Granell M, Urbano-Ispizua A, Wolff D, Hertenstein B, Greinix HT, Brenmoehl J, Schulz C, Dickinson AM, Hahn J, Rogler G, Andreesen R, Holler E. Recipient NOD2/CARD15 variants: a novel independent risk factor for the development of bronchiolitis obliterans after allogeneic stem cell transplantation. Biol Blood Marrow Transplant. 2008;14(1):67-74. https://doi.org/10.1016/j.bbmt.2007. 09.009 .

40. Holm AM, Riise GC, Hansson L, Brinch L, Bjortuft O, Iversen M, Simonsen S, Floisand Y. Lung transplantation for bronchiolitis obliterans syndrome after alloSCT. Bone Marrow Transplant. 2013;48(5):703-7. https://doi.org/10.1038/bmt.2012.197.

41. Hosokawa K, Yamazaki H, Nishitsuji M, Kobayashi S, Takami A, Fujimura M, Nakao S. Pulmonary venoocclusive disease following reduced-intensity allogeneic bone marrow transplantation for acute myeloid leukemia. Intern Med. 2012;51(2):195-8.

42. Ishii T, Manabe A, Ebihara Y, Ueda T, Yoshino H, Mitsui T, Hisakawa H, Yagasaki H, Kikuchi A, Yoshimasu T, Tanaka R, Takahashi T, Masunaga A, Sugita KI, Nakahata T, Asano S, Tsuji K. Improvement in bronchiolitis obliterans organizing pneumonia in a child after allogeneic bone marrow transplantation by a combination of oral prednisolone and low dose erythromycin. Bone Marrow Transplant. 2000;26(8): 907-10. https://doi.org/10.1038/sj.bmt.1702642.

43. Jagasia MH, Greinix HT, Arora M, Williams KM, Wolff D, Cowen EW, Palmer J, Weisdorf D, Treister NS, Cheng GS, Kerr H, Stratton P, Duarte RF, McDonald GB, Inamoto Y, Vigorito A, Arai S, Datiles MB, Jacobsohn D, Heller T, Kitko CL, Mitchell SA, Martin PJ, Shulman H, Wu RS, Cutler CS, Vogelsang GB, Lee SJ, Pavletic SZ, Flowers ME. National Institutes of Health consensus development project on criteria for clinical trials in chronic graft-versus-host disease: I. The 2014 diagnosis and staging working group report. Biol Blood Marrow Transplant. 2015;21(3):389-401. e381. https://doi.org/10.1016/j.bbmt.2014.12.001.

44. Jo KW, Yoon S, Song JW, Shim TS, Lee SW, Lee JS, Kim DY, Lee JH, Lee JH, Choi Y, Lee KH. The efficacy of prophylactic azithromycin on bronchiolitis obliterans syndrome after hematopoietic stem cell transplantation. Int J Hematol. 2015;102(3):357-63. https://doi.org/10.1007/s12185-015-1830-0.

45. Kantrow SP, Hackman RC, Boeckh M, Myerson D, Crawford SW. Idiopathic pneumonia syndrome: changing spectrum of lung injury after marrow transplantation. Transplantation. 1997;63(8):1079-86.

46. Kim SJ, Lee JW, Jung CW, Min CK, Cho B, Shin HJ, Chung JS, Kim H, Lee WS, Joo YD, Yang DH, Kook H, Kang HJ, Ahn HS, Yoon SS, Sohn SK, Min YH, Min WS, Park HS, Won JH. Weekly rituximab followed by monthly rituximab treatment for steroid-refractory chronic graft-versus-host disease: results from a prospective, multicenter, phase II study. Haematologica. 2010;95(11):1935-42. https://doi.org/ 10.3324/haematol.2010.026104.

47. Koinuma T, Nunomiya S, Wada M, Koyama K, Suzuki T. Concurrent treatment with a tumor necrosis factor-alpha inhibitor and veno-venous extracorporeal membrane oxygenation in a post-hematopoietic stem cell transplant patient with idiopathic pneumonia syndrome: a case report. J Intensive Care. 2014;2(1):48. https://doi.org/10.1186/s40560-014-0048-1.

48. Lam DC, Lam B, Wong MK, Lu C, Au WY, Tse EW, Leung AY, Kwong YL, Liang RH, Lam WK, Ip MS, Lie AK. Effects of azithromycin in bronchiolitis obliterans syndrome after hematopoietic SCT-a randomized double-blinded placebo-controlled study. Bone Marrow Transplant. 2011;46(12):1551-6. https://doi.org/10.1038/bmt.2011.1.

49. Landgren O, Gilbert ES, Rizzo JD, Socie G, Banks PM, Sobocinski KA, Horowitz MM, Jaffe ES, Kingma DW, Travis LB, Flowers ME, Martin PJ, Deeg HJ, Curtis RE. Risk factors for lymphoproliferative disorders after allogeneic hematopoietic cell transplantation. Blood. 2009;113(20):4992-5001. https://doi.org/10.1182/blood-2008-09-178046.

50. Lee KS, Kullnig P, Hartman TE, Muller NL. Cryptogenic organizing pneumonia: CT findings in 
43 patients. AJR Am J Roentgenol. 1994;162(3): 543-6. https://doi.org/10.2214/ajr.162.3.8109493.

51. Liao WI, Tsai SH, Chiu SK. Successful use of extracorporeal membrane oxygenation in a hematopoietic stem cell transplant patient with idiopathic pneumonia syndrome. Respir Care. 2013;58(2):e6-10. https://doi. org/10.4187/respcare.01716.

52. Lucid CE, Savani BN, Engelhardt BG, Shah P, Clifton C, Greenhut SL, Vaughan LA, Kassim A, Schuening F, Jagasia M. Extracorporeal photopheresis in patients with refractory bronchiolitis obliterans developing after allo-SCT. Bone Marrow Transplant. 2011;46 (3):426-9. https://doi.org/10.1038/bmt.2010.152.

53. Majeski EI, Paintlia MK, Lopez AD, Harley RA, London SD, London L. Respiratory reovirus $1 / \mathrm{L}$ induction of intraluminal fibrosis, a model of bronchiolitis obliterans organizing pneumonia, is dependent on T lymphocytes. Am J Pathol. 2003;163(4): 1467-79. https://doi.org/10.1016/S0002-9440(10) 63504-3.

54. Mandel J, Mark EJ, Hales CA. Pulmonary venoocclusive disease. Am J Respir Crit Care Med. 2000;162(5):1964-73. https://doi.org/10.1164/ajrccm. 162.5.9912045.

55. Mariani F, Gatti B, Rocca A, Bonifazi F, Cavazza A, Fanti S, Tomassetti S, Piciucchi S, Poletti V, Zompatori M. Pleuroparenchymal fibroelastosis: the prevalence of secondary forms in hematopoietic stem cell and lung transplantation recipients. Diagn Interv Radiol. 2016;22(5):400-6. https://doi.org/10.5152/dir.2016. 15516.

56. McCormack FX, Whitsett JA. The pulmonary collectins, SP-A and SP-D, orchestrate innate immunity in the lung. J Clin Invest. 2002;109(6):707-12. https://doi.org/10.1172/JCI15293.

57. Nakaseko C, Ozawa S, Sakaida E, Sakai M, Kanda Y, Oshima K, Kurokawa M, Takahashi S, Ooi J, Shimizu T, Yokota A, Yoshiba F, Fujimaki K, Kanamori H, Sakai R, Saitoh T, Sakura T, Maruta A, Sakamaki H, Okamoto S. Incidence, risk factors and outcomes of bronchiolitis obliterans after allogeneic stem cell transplantation. Int J Hematol. 2011;93(3): 375-82. https://doi.org/10.1007/s12185-011-0809-8.

58. Nakasone H, Onizuka M, Suzuki N, Fujii N, Taniguchi S, Kakihana K, Ogawa H, Miyamura K, Eto T, Sakamaki H, Yabe H, Morishima Y, Kato K, Suzuki R, Fukuda T. Pre-transplant risk factors for cryptogenic organizing pneumonia/bronchiolitis obliterans organizing pneumonia after hematopoietic cell transplantation. Bone Marrow Transplant. 2013;48 (10):1317-23. https://doi.org/10.1038/bmt. 2013.116.

59. Olivieri A, Locatelli F, Zecca M, Sanna A, Cimminiello M, Raimondi R, Gini G, Mordini N, Balduzzi A, Leoni P, Gabrielli A, Bacigalupo A. Imatinib for refractory chronic graft-versus-host disease with fibrotic features. Blood. 2009;114(3):709-18. https://doi.org/10.1182/blood-2009-02-204 156.

60. Panoskaltsis-Mortari A, Griese M, Madtes DK, Belperio JA, Haddad IY, Folz RJ, Cooke KR,
American Thoracic Society Committee on Idiopathic Pneumonia Syndrome. An official American Thoracic Society research statement: noninfectious lung injury after hematopoietic stem cell transplantation: idiopathic pneumonia syndrome. Am J Respir Crit Care Med. 2011;183(9):1262-79. https://doi.org/10.1164/ rccm.2007-413ST.

61. Paz HL, Crilley P, Patchefsky A, Schiffman RL, Brodsky I. Bronchiolitis obliterans after autologous bone marrow transplantation. Chest. 1992;101(3): 775-8.

62. Pena E, Souza CA, Escuissato DL, Gomes MM, Allan D, Tay J, Dennie CJ. Noninfectious pulmonary complications after hematopoietic stem cell transplantation: practical approach to imaging diagnosis. Radiographics. 2014;34(3):663-83. https://doi.org/10.1148/ rg.343135080.

63. Pipavath SN, Chung JH, Chien JW, Godwin JD. Organizing pneumonia in recipients of hematopoietic stem cell transplantation: CT features in 16 patients. J Comput Assist Tomogr. 2012;36(4):431-6. https:// doi.org/10.1097/RCT.0b013e31825ba274.

64. Poletti V, Cazzato S, Minicuci N, Zompatori M, Burzi M, Schiattone ML. The diagnostic value of bronchoalveolar lavage and transbronchial lung biopsy in cryptogenic organizing pneumonia. Eur Respir J. 1996;9(12):2513-6.

65. Ratjen F, Rjabko O, Kremens B. High-dose corticosteroid therapy for bronchiolitis obliterans after bone marrow transplantation in children. Bone Marrow Transplant. 2005;36(2):135-8. https://doi.org/10.1038/ sj.bmt. 1705026.

66. Sakaguchi H, Takahashi Y, Watanabe N, Doisaki S, Muramatsu H, Hama A, Shimada A, Yagasaki H, Kudo K, Kojima S. Incidence, clinical features, and risk factors of idiopathic pneumonia syndrome following hematopoietic stem cell transplantation in children. Pediatr Blood Cancer. 2012;58(5):780-4. https://doi. org/10.1002/pbc.23298.

67. Sakai R, Kanamori H, Nakaseko C, Yoshiba F, Fujimaki K, Sakura T, Fujisawa S, Kawai N, Onoda M, Matsushima T, Maruta A, Sakamaki H, Okamoto S. Air-leak syndrome following allo-SCT in adult patients: report from the Kanto Study Group for Cell Therapy in Japan. Bone Marrow Transplant. 2011;46 (3):379-84. https://doi.org/10.1038/bmt.2010. 129.

68. Sampath S, Schultheiss TE, Wong J. Dose response and factors related to interstitial pneumonitis after bone marrow transplant. Int $\mathrm{J}$ Radiat Oncol Biol Phys. 2005;63(3):876-84. https://doi.org/10.1016/j.ijrobp. 2005.02.032.

69. Santo Tomas LH, Loberiza FR Jr, Klein JP, Layde PM, Lipchik RJ, Rizzo JD, Bredeson CN, Horowitz MM. Risk factors for bronchiolitis obliterans in allogeneic hematopoietic stem-cell transplantation for leukemia. Chest. 2005;128(1):153-61. https://doi.org/10.1378/ chest.128.1.153.

70. Scarsbrook AF, Warakaulle DR, Dattani M, Traill Z. Post-transplantation lymphoproliferative disorder: the 
spectrum of imaging appearances. Clin Radiol. 2005;60(1):47-55. https://doi.org/10.1016/j.crad. 2004. 08.016 .

71. Schlatzer DM, Dazard JE, Ewing RM, Ilchenko S, Tomcheko SE, Eid S, Ho V, Yanik G, Chance MR, Cooke KR. Human biomarker discovery and predictive models for disease progression for idiopathic pneumonia syndrome following allogeneic stem cell transplantation. Mol Cell Proteomics. 2012;11(6):M111 015479. https://doi.org/10.1074/mcp.M111.015479.

72. Seo S, Renaud C, Kuypers JM, Chiu CY, Huang ML, Samayoa E, Xie H, Yu G, Fisher CE, Gooley TA, Miller S, Hackman RC, Myerson D, Sedlak RH, Kim YJ, Fukuda T, Fredricks DN, Madtes DK, Jerome KR, Boeckh M. Idiopathic pneumonia syndrome after hematopoietic cell transplantation: evidence of occult infectious etiologies. Blood. 2015;125(24):3789-97. https://doi.org/10.1182/blood2014-12-617035.

73. Shankar G, Scott Bryson J, Darrell Jennings C, Kaplan AM, Cohen DA. Idiopathic pneumonia syndrome after allogeneic bone marrow transplantation in mice. Role of pretransplant radiation conditioning. Am J Respir Cell Mol Biol. 1999;20(6):1116-24. https:// doi.org/10.1165/ajrcmb.20.6.3455.

74. Soubani AO, Pandya CM. The spectrum of noninfectious pulmonary complications following hematopoietic stem cell transplantation. Hematol Oncol Stem Cell Ther. 2010;3(3):143-57.

75. Spira D, Faul C, Schaup V, Wirths S, Schulze M, Sauter A, Horger M. HRCT findings in idiopathic pneumonia syndrome with documentation of the disease course. Eur J Radiol. 2012;81(2):e147-52. https:// doi.org/10.1016/j.ejrad.2011.01.055.

76. Srinivasan M, Flynn R, Price A, Ranger A, Browning JL, Taylor PA, Ritz J, Antin JH, Murphy WJ, Luznik L, Shlomchik MJ, PanoskaltsisMortari A, Blazar BR. Donor B-cell alloantibody deposition and germinal center formation are required for the development of murine chronic GVHD and bronchiolitis obliterans. Blood. 2012;119(6):1570-80. https://doi.org/10.1182/blood-2011-07-364414.

77. Styczynski J, van der Velden W, Fox CP, Engelhard D, de la Camara R, Cordonnier C, Ljungman P, Sixth European Conference on Infections in Leukemia, a joint venture of the Infectious Diseases Working Party of the European Society of Blood and Marrow Transplantation, the Infectious Diseases Group of the European Organization for Research and Treatment of Cancer, the International Immunocompromised Host Society and the European Leukemia Net. Management of Epstein-Barr Virus infections and post-transplant lymphoproliferative disorders in patients after allogeneic hematopoietic stem cell transplantation: Sixth European Conference on Infections in Leukemia (ECIL-6) guidelines. Haematologica. 2016;101(7):803-11. https://doi.org/10.3324/haematol. 2016.144428

78. Thirman MJ, Devine SM, O’Toole K, Cizek G, Jessurun J, Hertz M, Geller RB. Bronchiolitis obliterans organizing pneumonia as a complication of allogeneic bone marrow transplantation. Bone Marrow Transplant. 1992;10(3):307-11.

79. Thompson J, Yin Z, D'Souza A, Fenske T, Hamadani M, Hari P, Rizzo JD, Pasquini M, Saber W, Shah N, Shaw BE, Shahir K, Banerjee A, Drobyski WR. Etanercept and corticosteroid therapy for the treatment of late-onset idiopathic pneumonia syndrome. Biol Blood Marrow Transplant. 2017;23(11):1955-60. https://doi.org/10.1016/j.bbmt. 2017.07.019.

80. Tizon R, Frey N, Heitjan DF, Tan KS, Goldstein SC, Hexner EO, Loren A, Luger SM, Reshef R, Tsai D, Vogl D, Davis J, Vozniak M, Fuchs B, Stadtmauer EA, Porter DL. High-dose corticosteroids with or without etanercept for the treatment of idiopathic pneumonia syndrome after allo-SCT. Bone Marrow Transplant. 2012;47(10):1332-7. https://doi.org/10.1038/bmt. 2011.260.

81. Ueda K, Watadani T, Maeda E, Ota S, Kataoka K, Seo S, Kumano K, Hangaishi A, Takahashi T, Imai Y, Ohtomo K, Fukayama M, Nannya Y, Kurokawa M. Outcome and treatment of late-onset noninfectious pulmonary complications after allogeneic haematopoietic SCT. Bone Marrow Transplant. 2010;45(12):1719-27. https://doi.org/10.1038/bmt. 2010.48 .

82. Uhlving HH, Buchvald F, Heilmann CJ, Nielsen KG, Gormsen M, Muller KG. Bronchiolitis obliterans after allo-SCT: clinical criteria and treatment options. Bone Marrow Transplant. 2012;47(8):1020-9. https://doi. org/10.1038/bmt.2011.161.

83. Vande Vusse LK, Madtes DK. Early onset noninfectious pulmonary syndromes after hematopoietic cell transplantation. Clin Chest Med. 2017;38(2): 233-48. https://doi.org/10.1016/j.ccm.2016.12.007.

84. Vande Vusse LK, Madtes DK, Guthrie KA, Gernsheimer TB, Curtis JR, Watkins TR. The association between red blood cell and platelet transfusion and subsequently developing idiopathic pneumonia syndrome after hematopoietic stem cell transplantation. Transfusion. 2014;54(4):1071-80. https://doi.org/ $10.1111 /$ trf. 12396.

85. Vande Vusse LK, Madtes DK, Bolgiano D, Watkins TR. The association between platelet transfusion and idiopathic pneumonia syndrome is unaffected by platelet product type. Transfusion. 2016;56(2): 489-96. https://doi.org/10.1111/trf.13361.

86. Vogl UM, Nagayama K, Bojic M, Hoda MA, Klepetko W, Jaksch P, Dekan S, Siersch V, Mitterbauer M, Schellongowski P, Greinix HT, Petkov V, Schulenburg A, Kalhs P, Rabitsch W. Lung transplantation for bronchiolitis obliterans after allogeneic hematopoietic stem cell transplantation: a singlecenter experience. Transplantation. 2013;95(4):623-8. https://doi.org/10.1097/TP.0b013e318277e29e.

87. von der Thusen JH, Hansell DM, Tominaga M, Veys PA, Ashworth MT, Owens CM, Nicholson AG. Pleuroparenchymal fibroelastosis in patients with 
pulmonary disease secondary to bone marrow transplantation. Mod Pathol. 2011;24(12):1633-9. https:// doi.org/10.1038/modpathol.2011.114.

88. Vos R, Vanaudenaerde BM, Verleden SE, De Vleeschauwer SI, Willems-Widyastuti A, Van Raemdonck DE, Schoonis A, Nawrot TS, Dupont LJ, Verleden GM. A randomised controlled trial of azithromycin to prevent chronic rejection after lung transplantation. Eur Respir J. 2011;37(1):164-72. https://doi.org/10.1183/09031936.00068310.

89. Watanabe K. Pleuroparenchymal fibroelastosis: its clinical characteristics. Curr Respir Med Rev. 2013;9:299-37. https://doi.org/10.2174/1573398X09 04140129125307.

90. Weiner RS, Bortin MM, Gale RP, Gluckman E, Kay HE, Kolb HJ, Hartz AJ, Rimm AA. Interstitial pneumonitis after bone marrow transplantation. Assessment of risk factors. Ann Intern Med. 1986;104(2):168-75.

91. Williams KM. How I treat bronchiolitis obliterans syndrome after hematopoietic stem cell transplantation. Blood. 2017;129(4):448-55. https://doi.org/10.1182/ blood-2016-08-693507.

92. Williams KM, Cheng GS, Pusic I, Jagasia M, Burns L, Ho VT, Pidala J, Palmer J, Johnston L, Mayer S, Chien JW, Jacobsohn DA, Pavletic SZ, Martin PJ, Storer BE, Inamoto $\mathrm{Y}$, Chai $\mathrm{X}$, Flowers MED, Lee SJ. Fluticasone, azithromycin, and montelukast treatment for new-onset bronchiolitis obliterans syndrome after hematopoietic cell transplantation. Biol Blood Marrow Transplant. 2016;22(4):710-6. https:// doi.org/10.1016/j.bbmt.2015.10.009.

93. Woodard JP, Gulbahce E, Shreve M, Steiner M, Peters C, Hite S, Ramsay NK, DeFor T, Baker KS. Pulmonary cytolytic thrombi: a newly recognized complication of stem cell transplantation. Bone Marrow Transplant. 2000;25(3):293-300. https://doi.org/ 10.1038/sj.bmt.1702137.

94. Yang S, Milla C, Panoskaltsis-Mortari A, Ingbar DH, Blazar BR, Haddad IY. Human surfactant protein a suppresses $\mathrm{T}$ cell-dependent inflammation and attenuates the manifestations of idiopathic pneumonia syndrome in mice. Am $\mathrm{J}$ Respir Cell Mol Biol. 2001;24(5):527-36. https://doi.org/10.1165/ajrcmb. 24.5.4400.

95. Yanik GA, Mineishi S, Levine JE, Kitko CL, White ES, Vander Lugt MT, Harris AC, Braun T, Cooke KR. Soluble tumor necrosis factor receptor: enbrel (etanercept) for subacute pulmonary dysfunction following allogeneic stem cell transplantation. Biol Blood Marrow Transplant. 2012;18(7):1044-54. https://doi. org/10.1016/j.bbmt.2011.11.031.

96. Yanik GA, Horowitz MM, Weisdorf DJ, Logan BR, Ho VT, Soiffer RJ, Carter SL, Wu J, Wingard JR, Difronzo NL, Ferrara JL, Giralt S, Madtes DK, Drexler R, White ES, Cooke KR. Randomized, double-blind, placebo-controlled trial of soluble tumor necrosis factor receptor: enbrel (etanercept) for the treatment of idiopathic pneumonia syndrome after allogeneic stem cell transplantation: blood and marrow transplant clinical trials network protocol. Biol Blood Marrow Transplant. 2014;20(6):858-64. https://doi. org/10.1016/j.bbmt.2014.02.026.

97. Yanik GA, Grupp SA, Pulsipher MA, Levine JE, Schultz KR, Wall DA, Langholz B, Dvorak CC, Alangaden K, Goyal RK, White ES, Collura JM, Skeens MA, Eid S, Pierce EM, Cooke KR. TNF-receptor inhibitor therapy for the treatment of children with idiopathic pneumonia syndrome. A joint Pediatric Blood and Marrow Transplant Consortium and Children's Oncology Group Study (ASCT0521). Biol Blood Marrow Transplant. 2015;21(1):67-73. https://doi.org/10.1016/j.bbmt. 2014.09.019.

98. Yoshihara S, Yanik G, Cooke KR, Mineishi S. Bronchiolitis obliterans syndrome (BOS), bronchiolitis obliterans organizing pneumonia (BOOP), and other late-onset noninfectious pulmonary complications following allogeneic hematopoietic stem cell transplantation. Biol Blood Marrow Transplant. 2007;13(7): 749-59. https://doi.org/10.1016/j.bbmt.2007.05.001. 